\title{
Use of the SYBR Green I fluorescent dye and a centrifugal filter device for rapid determination of dissolved DNA concentration in fresh water
}

\author{
Kazuaki Matsui ${ }^{1, *}$, Nobuyoshi Ishii ${ }^{2}$, Mie Honjo ${ }^{3}$, Zen'ichiro Kawabata ${ }^{3}$ \\ ${ }^{1}$ Laboratory of Environmental Biotechnology, Faculty of Engineering, Tohoku Gakuin University, 1-13-1 Chuo, Tagajo, \\ Miyagi 985-8537, Japan \\ ${ }^{2}$ Environmental and Toxicological Science Research Group, National Institute of Radiological Sciences, 9-1 \\ Anagawa-4-chome, Inage-ku, Chiba-shi 263-8555, Japan \\ ${ }^{3}$ Center for Ecological Research, Kyoto University, Kamitanakami Hirano-cho 509-3, Otsu 520-2113, Japan
}

\begin{abstract}
A rapid fluorometric assay using the fluorescent dye SYBR Green I was established to determine the concentration of dissolved nucleic acids in fresh water. The sensitivity of SYBR Green I to double stranded DNA (dsDNA) ( $\lambda$ Hind III digest) was as low as 50 pg, 200 times more sensitive than Hoechst 33258. SYBR Green I bound to dsDNA emitted 10 times stronger fluorescence than when bound to single stranded DNA or RNA, indicating its selectivity for dsDNA measurement. The dissolved DNA (dDNA) concentration in fresh water determined using SYBR Green I was almost the same as that obtained using Hoechst 33258. This suggests that the dDNA measured by SYBR Green I is comparable to that determined by Hoechst 33258 in previous studies. To reduce preparation time, the dDNA in lake water filtrate was precipitated by ethanol and purified using a centrifugal filter device. The overall preparation process takes only a few hours and requires only $10 \mathrm{ml}$ of water. The process described here may, therefore, facilitate 'same day' measurement of dDNA dynamics in freshwater environments.
\end{abstract}

KEY WORDS: Dissolved DNA · SYBR Green I - Ethanol precipitation - Centrifugal filter device · Extracellular DNA · Fresh water

\section{INTRODUCTION}

Dissolved DNA (dDNA, which passes through a $0.2 \mu \mathrm{m}$ pore filter) is a form of extracellular DNA and a common constituent of the dissolved organic matter (DOM) in all natural aquatic environments. Although viruses are included in this $<0.2 \mu \mathrm{m}$ fraction, previous studies have demonstrated that virus DNA only accounts for less than $20 \%$ of the total dDNA pool (Paul et al. 1991b, Weinbauer et al. 1993) and thus the majority of dDNA is composed of either soluble or particle-binding forms of naked DNA (Jiang \& Paul 1995). Although the function of dDNA in aquatic environments is still not fully understood, it is regarded as an attractive nutritional source for aquatic microorganisms (Turk et al. 1992, Jørgensen \& Jacobsen 1996). In this context, Siuda \& Chróst (2000) have recently demonstrated that 11 to $27.6 \%$ of the total phosphorus concentration in German lakes is accounted for by enzymatically liberated phosphorus from dDNA. In addition to its nutritional importance, dDNA could also be important as an extracellular genetic pool for further bacterial horizontal gene transfer, via natural transformation (Lorenz \& Wackernagel 1994, Matsui et al. 2001, 2003). Thus, as with physico-chemical water characteristics (e.g. determination of nutrients), determination of dDNA concentration has become an important parameter to characterize an aquatic ecosystem.

Following the first determinations of dissolved nucleic acid in marine (Pillai \& Ganguly 1972) and freshwater environments (Minear 1972), the amount of dDNA has 
been determined repeatedly in various aquatic environments and found at concentrations from 0.5 to $88 \mu \mathrm{g}$ $\mathrm{l}^{-1}$ in fresh waters (e.g. Karl \& Bailiff 1989, Paul et al. 1989, 1991a, Siuda \& Güde 1996, Siuda et al. 1998). The fluorometric assay, based on enhancement of the fluorescence of dyes upon DNA binding, is widely used as a simple and reliable method to determine the amount of dDNA. Hoechst 33258 (bisbenzimide), and DAPI (4', 6diamidino-2-phenylindole) fluorescent dyes specific for double stranded DNA (dsDNA), have been used for this purpose. However, because of the sensitivity levels of these dyes, at least $100 \mathrm{ng}$ (for Hoechst 33258; DeFlaun et al. 1986) and 50 to $60 \mathrm{ng}$ (for DAPI; Siuda \& Güde 1996) of DNA is necessary for reliable measurement. To achieve this, dDNA must be adequately concentrated from 0.1 to $10 \mathrm{l}$ of sample water before analysis. The concentration of dDNA from large volumes of water is very time consuming and becomes a burden for routine dDNA measurement. Moreover, long manipulation times may influence the production and consumption rates of dDNA in sampled water and thus bias the dDNA determination.

The aim of this study was to develop a rapid and reliable procedure for routine measurement of dDNA. For this purpose we used SYBR Green I (Molecular Probes) to enhance the sensitivity of dDNA measurement. SYBR Green I is a sensitive cyanine dye specific to dsDNA originally developed for gel staining. It has been applied in aquatic microbial ecology for studies such as the determination of virus abundance (Noble \& Fuhrman 1998). In laboratory solution assays, the sensitivity of SYBR Green I is 6 to 8 times greater than that of ethidium bromide, a fluorescent dye commonly used for gel staining (Vitzthum et al. 1999), and is thus attractive for the determination of the dDNA concentration in small volumes of water. We have also modified the ethanol dDNA precipitation method (DeFlaun et al. 1986) by combining it with a centrifugal filter device to reduce the time required for DNA desalting. The overall process allowed us to determine the dDNA concentration from a $10 \mathrm{ml}$ water sample within a few hours, and may facilitate the routine measurement of dDNA in aquatic environments.

\section{MATERIALS AND METHODS}

Sample collection. To test the applicability of SYBR Green I for environmental samples, lake water samples were collected from 2.5 and $50 \mathrm{~m}$ depth at a pelagic station $\left(35^{\circ} 10^{\prime} \mathrm{N}, 135^{\circ} 56^{\prime} \mathrm{E}\right.$; $\sim 57 \mathrm{~m}$ depth) in the mesotrophic north basin of Lake Biwa during the stratification period (3 July 2002). The detailed geographical and limnological characteristics of this sampling station have been described by Gurung \& Urabe
(1999). To test the effectiveness of the centrifugal filter device, samples were also taken from the surface near the shore in several freshwater environments of different trophic status (10 to 27 November 2003). The samples obtained were immediately transferred to the laboratory and all experimental treatments were conducted within $5 \mathrm{~h}$ of sampling.

Analytical measurements. Total phosphorus was measured according to Menzel \& Corwin (1965). Total nitrogen was converted to nitrate by alkaline persulfate oxidation $\left(\mathrm{H}_{3} \mathrm{BO}_{3}\right.$ was omitted from the oxidization reagent) and determined by an ultraviolet spectrophotometric screening method (Eaton et al. 1995). Chlorophyll a (chl a) was determined by standard fluorometric methods (Wetzel \& Likens 2000). Bacteria and virus-like particles (VLPs) were enumerated directly under an epifluorescence microscope, using the DAPI staining method for bacteria (Porter \& Feig 1980) and the SYBR Green I staining method for VLPs (Noble \& Fuhrman 1998). The trophic state index was calculated from the amount of total phosphorus, according to Carlson (1977).

Concentration and purification of dDNA. The freshwater samples were each passed through a filter combination consisting of a $10 \mu \mathrm{m}$ pore filter (coated cellulose acetate on non-woven polyester; Advantec) and a $0.2 \mu \mathrm{m}$ pore filter (polycarbonate; Advantec) under a vacuum of less than $150 \mathrm{~mm} \mathrm{Hg}$. Each filtrate was then divided into 8 subsamples of equal volume. Three were replicates and the next 3 were enriched with 10 to $20 \mu \mathrm{g} \mathrm{l}^{-1}$ final concentration of $\lambda$ Hind III digested DNA to assess recovery. Of the remaining 2, one was treated with DNase I (final concentration $100 \mathrm{\mu g} \mathrm{ml}^{-1}$, Sigma) and the other with a mixture of DNase I and RNase A (final concentration $100 \mu \mathrm{g} \mathrm{ml}^{-1}$ each, Sigma) to verify that the detected fluorescence was due to DNA. The DNase I and/or RNase A treatments were conducted at $37^{\circ} \mathrm{C}$ for $2 \mathrm{~h}$ with $\mathrm{MgCl}_{2}$ supplementation (final concentration was $500 \mu \mathrm{M}$ ).

Two commonly used dDNA concentration procedures, the N-cetyl N,N,N-trimethylammonium bromide (CTAB) nucleic acid precipitation method (e.g. Karl \& Bailiff 1989, Siuda \& Güde 1996, Ishii et al. 1998) and the ethanol (EtOH) precipitation method (e.g. DeFlaun et al. 1986, Paul \& Pichard 1995), were compared for their suitability for fluorescence measurement with SYBR Green I.

CTAB nucleic acid precipitation was based on the method of Karl \& Bailiff (1989), as modified by Ishii et al. (1998). Briefly, $2 \mathrm{ml}$ of CTAB stock solution (5 $\mathrm{g}$ of CTAB in 11 of $0.5 \mathrm{M} \mathrm{NaCl}$ ) was added to each $100 \mathrm{ml}$ of $0.2 \mu \mathrm{m}$ filtrate. The filtrates supplemented with CTAB were completely frozen at $-20^{\circ} \mathrm{C}$, thawed at room temperature, and then the insoluble dDNA-CTA complex was trapped onto $0.2 \mu \mathrm{m}$ pore polycarbonate filters. The filters were immersed in $4 \mathrm{ml}$ of $\mathrm{NaCl}$ buffer 
(2 $\mathrm{M} \mathrm{NaCl}, 6 \mathrm{mM}$ Tris-Cl pH 8.0, 0.6 mM EDTA) at $65^{\circ} \mathrm{C}$ for $0.5 \mathrm{~h}$, and then mixed with $4 \mathrm{ml}$ of CIAA (chloroform:isoamyl alcohol; 24:1) to dissolve the filter. The soluble DNA sodium salts were separated from the CIAA by brief centrifugation and the supernatant collected was purified by ethanol precipitation (Sambrook \& Russell 2000) and then re-dissolved in TE buffer for final dDNA determination.

The EtOH dDNA precipitation procedure was based on the method of DeFlaun et al. (1986) as follows. Each $100 \mathrm{ml}$ of $0.2 \mu \mathrm{m}$ filtrate was supplemented with $10 \mathrm{ml}$ of salts solution $\left(1.3 \mathrm{M} \mathrm{NaCl}\right.$ and $0.135 \mathrm{M} \mathrm{MgSO}_{4}$. $7 \mathrm{H}_{2} \mathrm{O}$ ) and $1 \mathrm{ml}$ of $0.54 \mathrm{M} \mathrm{CaCl}_{2} \cdot 2 \mathrm{H}_{2} \mathrm{O}$ solution. DNA was precipitated by the addition of $220 \mathrm{ml}$ of ethanol and kept at $-20^{\circ} \mathrm{C}$ for $48 \mathrm{~h}$. The precipitated DNA salt complex was collected by centrifugation $(7000 \times g$ for $20 \mathrm{~min}$, at $4^{\circ} \mathrm{C}$ ). The precipitated pellet was dialyzed against distilled water at $4^{\circ} \mathrm{C}$, the buffer being changed twice per day until the precipitate was removed (as determined by eye), and then against TE buffer (10 mM Tris-Cl and $1 \mathrm{mM}$ EDTA, pH 8.0) for $12 \mathrm{~h}$. The dialyzed sample was used for the final dDNA determination.

Purification of dDNA with a centrifugal filter device. The dDNA in 10 or $100 \mathrm{ml}$ of lake water filtrate $(<0.2 \mu \mathrm{m})$ was precipitated by the EtOH method as described above. After 0, 24, or 48 h of DNA precipitation, the DNA salt complex was collected by centrifugation $\left(7000 \times g\right.$ for $20 \mathrm{~min}$, at $\left.4^{\circ} \mathrm{C}\right)$. The precipitated pellet was lightly dried at room temperature for $5 \mathrm{~min}$ (complete desiccation resulted in difficult re-dissolving), re-dissolved in $5 \mathrm{ml}$ of TE buffer and then concentrated with a 30000 -molecular-weight-cutoff centrifugal filter device (CENTRIPLUS; Millipore) to about 100 to $200 \mu l$. Since salts remaining in the concentrate quench SYBR Green I fluorescence (Vitzthum et al. 1999, Matsui et al. unpubl. data), the concentrate was further washed twice with $5 \mathrm{ml}$ of TE in the same device and the filter-retained dDNA concentrate was used for the final dDNA determination.

Determination of DNA. DNA concentration was determined spectrofluorometrically by an increment method (Paul \& Myers 1982). This method accounts for quenching effects in working dye solutions since all standards are internal. The supplied concentrations of SYBR Green I and Pico Green (Molecular Probes) were diluted with TE buffer $1.6 \times 10^{-4}$ and $5 \times 10^{-3}$ times respectively, and used as working fluorescent dye solutions. Hoechst 33258 (Wako Chemical) working dye solution $\left(1.5 \times 10^{-7} \mathrm{M}\right.$ in TE buffer) was prepared following the method of Paul \& Myers (1982). Two ml of the working fluorescent dye solution were placed in a $1 \mathrm{~cm}$ quartz cuvette in a spectrofluorometer (RF5300PC, Shimadzu) with a slit width of $10 \mathrm{~nm}$. Fluorescence excitation and emission spectra were settled at 494 and $524 \mathrm{~nm}$ (SYBR Green I), 483 and $524 \mathrm{~nm}$ (Pico Green) and 342 and 472 nm (Hoechst 33258), respectively. $\lambda$ Hind III digested DNA (Takara Shuzo) was used as the standard for dsDNA. Each 2 to $10 \mu \mathrm{l}$ of dDNA sample and the standard DNA were serially spiked into a working dye solution and the fluorescence was measured after each increment. The slope of the regression line of the fluorescence intensity versus DNA added was used to determine the concentration of the dDNA sample. All measurements were corrected for the fluorescence obtained from the DNase I treated sample (Paul \& Myers 1982). To evaluate the specificity of the dyes for dsDNA, the fluorescence intensity for each fluorescent dye was also evaluated with fish sperm single stranded DNA (ssDNA; MBgrade, Roche Diagnostics) and yeast RNA (Wako Chemical), and the slopes of these regression lines were compared. Variations in the dDNA concentrations detected were examined by analysis of variance (ANOVA), with post-hoc Fisher's PLSD test using Stat View 5.0 for Macintosh (SAS Institute).

\section{RESULTS AND DISCUSSION}

\section{Comparison of the specificity of fluorescence dyes}

Fig. 1 shows the relationship of fluorescent signal intensity against the amount of $\lambda$ Hind III digested DNA in $2 \mathrm{ml}$ of $1.6 \times 10^{-4}$ diluted SYBR Green I solution. The correlation coefficient for the linear regression was 0.999 over the range from $50 \mathrm{pg}$ to $32 \mathrm{ng}$ of $\lambda$ Hind III digested DNA standards. Thus,

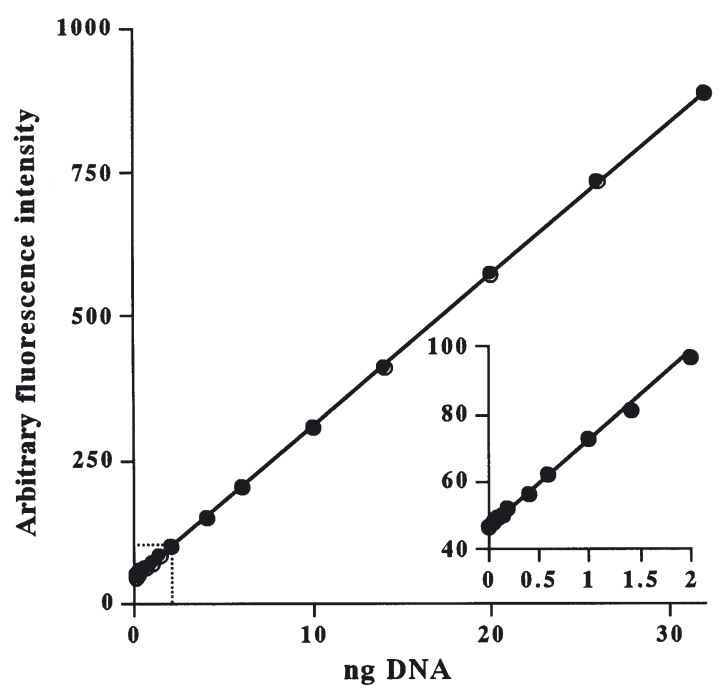

Fig. 1. Regression of the fluorescence intensity against the amount of $\lambda$ Hind III digested DNA in $2 \mathrm{ml}$ of $1.6 \times 10^{-4}$ diluted SYBR Green I solution 
SYBR Green I can detect as little as $50 \mathrm{pg}$ of DNA in 2 to $10 \mu \mathrm{l}$ of sample and this is 200 times more sensitive than Hoechst 33258 dye (Labarca \& Paigen 1980).

The selectivity of SYBR Green I for dsDNA, ssDNA and yeast RNA was compared with those of Pico Green and Hoechst 33258. SYBR Green I displayed 10 times more fluorescence when bound to dsDNA than when bound to fish sperm ssDNA and yeast RNA (Fig. 2). Pico Green also showed high selectivity for dsDNA, but the sensitivity was slightly lower than that of SYBR Green I. In a previous study, Vitzthum et al. (1999) also reported that the sensitivity of SYBR Green I for dsDNA is 1.4 to 1.8 times higher than that of Pico Green and the same tendency was observed in our study. Hoechst 33258 displayed 10 times weaker fluorescence with dsDNA compared to SYBR Green I and Pico Green. Thus, SYBR Green I is an attractive dye for dDNA determination with high sensitivity and selectivity for dsDNA. We therefore tested the effectiveness of this dye for environmental dDNA analysis further.

\section{Determination of environmental dDNA concentration with SYBR Green I}

An assay conducted as a pure laboratory experiment is not completely applicable for use with environmental samples. A commonly used standard method, which

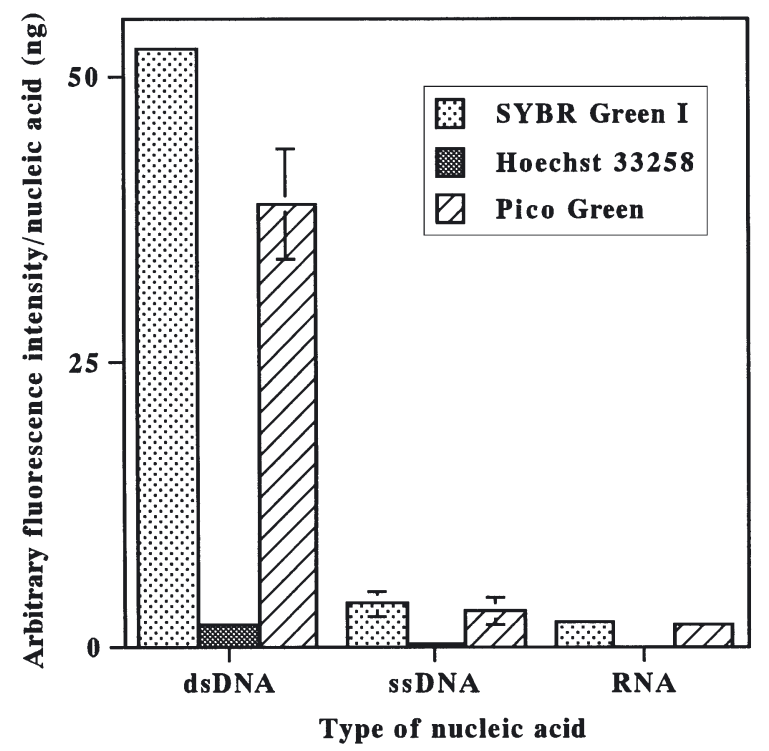

Fig. 2. Specificity of fluorescence dyes for double stranded DNA (dsDNA) ( $\lambda$ Hind III digest), single stranded DNA (ssDNA) (fish sperm) and yeast RNA. Slope of the linear regression (fluorescence intensity against increment of nucleic acid) is shown. Error bars indicate the standard deviations from the means of triplicate experiments. Where there are no error bars, the line was smaller than the symbol constructs a calibration series of standard DNA separately (Paul \& Myers 1982), does not allow for the fluorescent interference sometimes present in DNA purified from natural water. To evaluate the effectiveness of this new method, we therefore employed an increment method and measured freshwater dDNA using both SYBR Green I and Hoechst 33258 (Fig. 3). The recovery efficiency of the added $\lambda$ Hind III DNA standards from samples of epilimnion and hypolimnion lake water averaged $60.8( \pm 4.2) \%$ for the CTAB method and $88.6( \pm 4.7) \%$ for the EtOH method. No significant difference was observed between the dDNA concentrations determined with SYBR Green I and with Hoechst 33258 ( $p>0.07$, by ANOVA). Neither SYBR Green I nor Hoechst 33258 were influenced by the different dDNA precipitation procedures (CTAB vs EtOH), or by the different sampling depths (epilimnion vs hypolimnion). The DNase I treatment removed 90 to $99 \%$ of the DNA fluorescence in both the SYBR Green I and Hoechst 33258 assays, and the addition of RNase A did not reduce fluorescence any further (data not shown). Thus, RNA only contributed a negligible fraction of the fluorescence detected and we therefore corrected all measurements using fluorescence obtained from the DNase I treatment.

These data indicate that SYBR Green I can be used for the measurement of environmental dDNA. The data obtained are comparable with those obtained

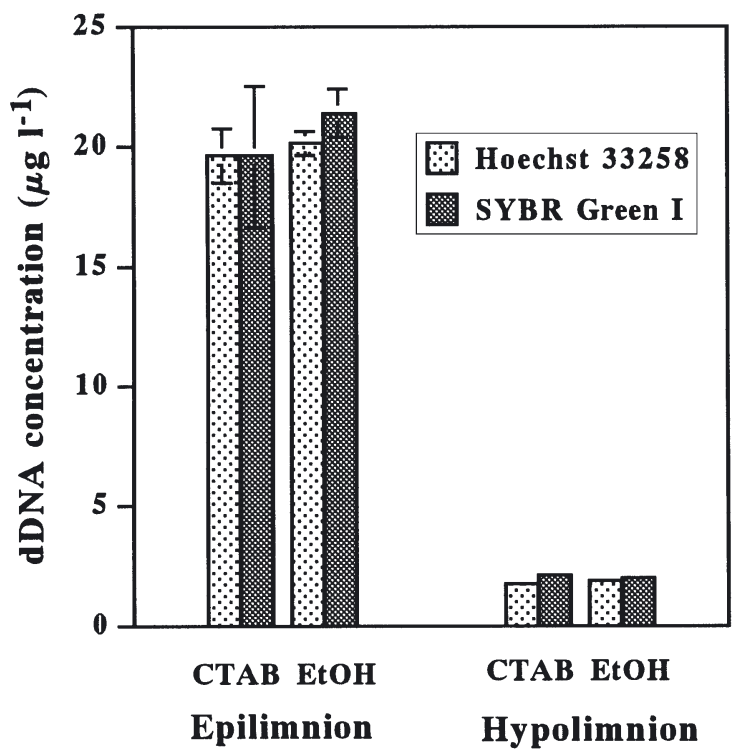

Fig. 3. Concentration of dissolved DNA (dDNA) in epilimnion and hypolimnion lake water. dDNA was concentrated by either the CTAB-method or the EtOH-method and determined by either SYBR Green I or Hoechst 33258. Error bars indicate the standard deviations from the means of triplicate experiments. Where there are no error bars, the line was smaller than the symbol 
using Hoechst 33258 in previous studies. Of note, the final concentration ratios of the lake water filtrates were 100 times (for SYBR Green I) and 10000 times (for Hoechst 33258), respectively. The measurement of dDNA by an increment method requires 10 to $50 \mu \mathrm{l}$ of dDNA concentrate. Accounting for the efficiency of dDNA recovery, $10 \mathrm{ml}$ of water sample should be sufficient for reliable dDNA determination with SYBR Green I. Since the EtOH method showed a higher dDNA recovery efficiency than the CTAB method, we purified the dDNA from a $10 \mathrm{ml}$ water sample using EtOH precipitation and tested its effectiveness at the next stage of our study.

\section{Purification of EtOH-concentrated dDNA with a centrifugal filter device}

The detection of as little as 50 pg of DNA with SYBR Green I (Fig. 1) suggested that it is possible to measure dDNA concentration directly from intact lake water filtrate. However, the addition of non-treated lake water filtrate (3 July 2002) into a working dye solution did not permit the measurement of dDNA because of high background fluorescence in the filtrate (data not shown). Thus, dDNA in a $0.2 \mu \mathrm{m}$ filtrate must be selectively concentrated and purified to avoid fluorescence interference. The EtOH method is a widely used technique for dDNA concentration (DeFlaun et al. 1986) and its dDNA recovery efficiency was higher than that of the CTAB method in our study at Lake Biwa. Although the principle is simple and reliable, the $\mathrm{EtOH}$ method is time consuming ( $48 \mathrm{~h}$ for DNA precipitation and 2 to $3 \mathrm{~d}$ for desalting by dialysis). To establish a rapid and reliable dDNA determination method, we applied a centrifugal filter device instead of dialysis, to reduce the time for required DNA desalting. Fig. 4 shows the amount of dDNA detected in Lake Kuwanuma (trophic state index, $\mathrm{TSI}_{\mathrm{PT}}=32$ ) and Lake Agawanuma $\left(\mathrm{TSI}_{\mathrm{PT}}=80\right)$, and the recovery efficiencies using centrifugal filter devices. The dDNA concentration obtained and the recovery efficiency were not influenced by the DNA precipitation period $(0,24$, and $48 \mathrm{~h}$ ) or by the initial volume of the sample (10 or $100 \mathrm{ml})(\mathrm{p}>0.08$, by ANOVA). EtOH precipitation is a commonly used technique in molecular biology and a recent protocol noted that it is unnecessary to precipitate the DNA at low temperature, and that 15 to $30 \mathrm{~min}$ precipitation is sufficient (Sambrook \& Russell 2000). Although the DNA recovery efficiency was slightly lower than that of previous studies $(>90 \%$; DeFlaun et

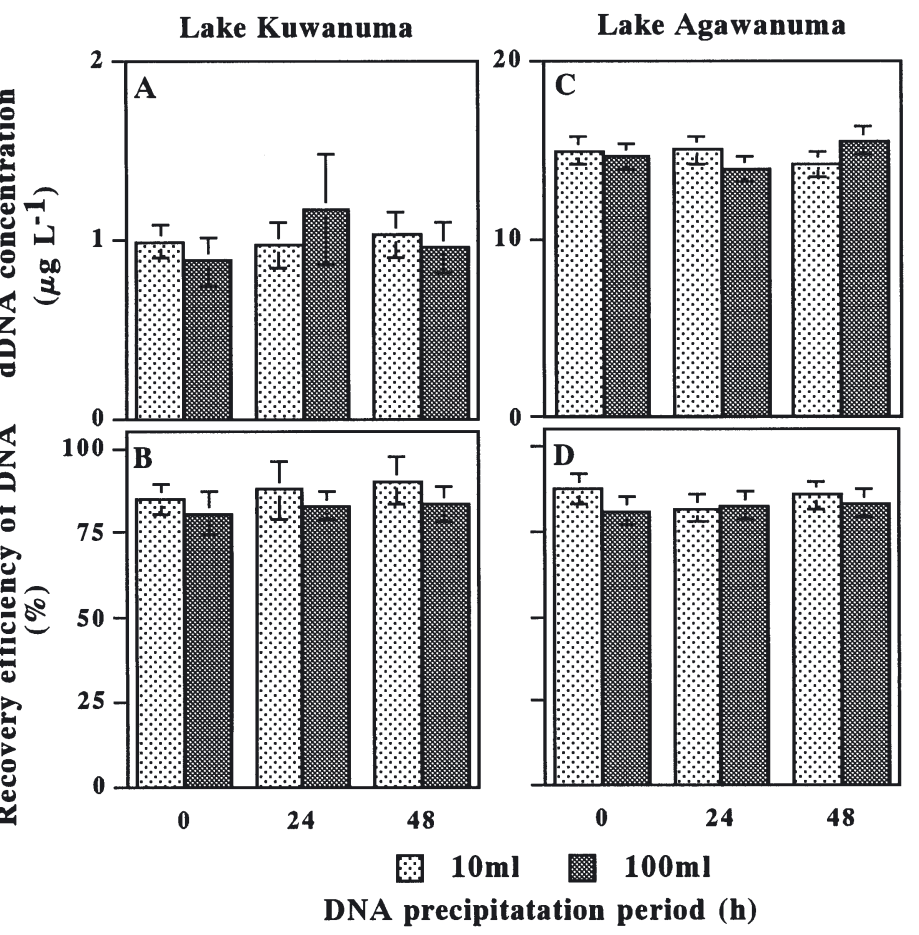

Fig. 4. $(\mathrm{A}, \mathrm{C})$ Amount of dDNA detected and $(\mathrm{B}, \mathrm{D})$ the recovery efficiency of the standard DNA ( $\lambda$ Hind III digest) added in $(A, B)$ Lake Kuwanuma and $(\mathrm{C}, \mathrm{D})$ Lake Agawanuma. dDNA was precipitated from either 10 or $100 \mathrm{ml}$ of filtrate for 0,24 , or $48 \mathrm{~h}$ by the $\mathrm{EtOH}$ method. Each precipitated dDNA sample was further desalted using a centrifugal filter device instead of the usual dialysis. Error bars indicate the standard deviations from the means of triplicate experiments

al. 1986), detection of dDNA from environments of different trophic status suggested the applicability of this method for many freshwater environments. Furthermore, we determined the dDNA concentration in various freshwater environments (Table 1) and found similar concentrations to those reported in previous studies (DeFlaun et al. 1986, Paul et al. 1989, 1991a). As in the study of the Lake Biwa pelagic station, DNase I treatment removed 90 to $99 \%$ of the DNA fluorescence, and the treatment with a mixture of DNase I and RNase A did not reduce fluorescence further (data not shown). These results may suggest that the dDNA detected is an enzymatically hydrolysable form, while the dDNA phosphorus contributes only $0.28 \%$ (Lake Kasenuma) to $3.6 \%$ (Lake Biwa, north basin) of the total phosphorus in the waters studied, contributing much less than previously reported (Siuda \& Chróst 2000). Simple correlation analysis showed high product-moment correlation coefficients between dDNA concentration and VLP numbers $(\mathrm{r}=0.897, \mathrm{p}<0.01)$ (Table 2). Some other variables (total nitrogen, bacterial abundance and $\mathrm{TSI}_{\mathrm{PT}}$ ) also correlated with dDNA concentration $(\mathrm{p}<0.05)$, while chl $a$ and total phospho- 
Table 1. Concentration of dissolved DNA (dDNA) determined by the presented method from 10 ml of sample, and basic limnological parameters of studied freshwater habitats. Sites are arranged according to increasing trophic state index calculated from $\mathrm{P}_{\mathrm{T}}\left(\mathrm{TSI}_{\mathrm{PT}}\right)$. $\mathrm{P}_{\mathrm{T}}$ : total phosphorus; $\mathrm{N}_{\mathrm{T}}$ : total nitrogen; $\mathrm{BA}$ : bacterial abundance; VLPs: number of virus-like particles; Chl a: chlorophyll a

\begin{tabular}{|c|c|c|c|c|c|c|c|}
\hline Sample location & $\begin{array}{c}\mathrm{P}_{\mathrm{T}} \\
\left(\mu \mathrm{g} \mathrm{l}^{-1}\right)\end{array}$ & $\begin{array}{c}\mathrm{N}_{\mathrm{T}} \\
\left(\mu \mathrm{g} \mathrm{l}^{-1}\right)\end{array}$ & $\begin{array}{c}\text { BA } \\
\left(10^{6} \text { cells ml }{ }^{-1}\right)\end{array}$ & $\begin{array}{c}\text { VLPs } \\
\left(10^{6} \mathrm{VLP} \mathrm{m}^{-1}\right)\end{array}$ & $\begin{array}{l}\text { Chl a } \\
\left(\mu g l^{-1}\right)\end{array}$ & $\begin{array}{l}\text { dDNA } \\
\left(\mu \mathrm{g} \mathrm{l}^{-1}\right)\end{array}$ & $\mathrm{TSI}_{\mathrm{PT}}$ \\
\hline $\begin{array}{l}\text { Lake Kuwanuma } \\
\left(38^{\circ} 26^{\prime} \mathrm{N}, 140^{\circ} 42^{\prime} \mathrm{E}\right)\end{array}$ & 7.1 & 312.2 & 0.7 & 5.2 & 4.2 & $0.99 \pm 0.09$ & 32 \\
\hline $\begin{array}{l}\text { Lake Biwa (North Basin) } \\
\left(35^{\circ} 27^{\prime} \mathrm{N}, 136^{\circ} 08^{\prime} \mathrm{E}\right)\end{array}$ & 12.7 & 446.7 & 1.0 & 6.7 & 2.3 & $4.64 \pm 0.81$ & 40 \\
\hline $\begin{array}{l}\text { Kamafusa Reserver } \\
\left(38^{\circ} 12^{\prime} \mathrm{N}, 140^{\circ} 41^{\prime} \mathrm{E}\right)\end{array}$ & 17.3 & 719.4 & 2.6 & 12.0 & 4.5 & $4.68 \pm 0.35$ & 45 \\
\hline $\begin{array}{l}\text { Ookura Reserver } \\
\left(38^{\circ} 20^{\prime} \mathrm{N}, 140^{\circ} 42^{\prime} \mathrm{E}\right)\end{array}$ & 21.2 & 442.8 & 1.4 & 4.9 & 2.0 & $1.36 \pm 0.11$ & 48 \\
\hline $\begin{array}{l}\text { Lake Biwa (South Basin) } \\
\left(34^{\circ} 58^{\prime} \mathrm{N}, 135^{\circ} 55^{\prime} \mathrm{E}\right)\end{array}$ & 33.2 & 938.5 & 1.4 & 9.7 & 5.9 & $3.92 \pm 0.83$ & 54 \\
\hline $\begin{array}{l}\text { Lake Kasenuma } \\
\left(38^{\circ} 19^{\prime} \mathrm{N}, 141^{\circ} 00^{\prime} \mathrm{E}\right)\end{array}$ & 185.2 & 1910.1 & 2.4 & 13.5 & 1.1 & $5.36 \pm 0.36$ & 79 \\
\hline $\begin{array}{l}\text { Lake Agawanuma } \\
\left(38^{\circ} 17^{\prime} \mathrm{N}, 141^{\circ} 04^{\prime} \mathrm{E}\right)\end{array}$ & 192.8 & 1800.2 & 9.4 & 16.7 & 39.0 & $14.93 \pm 0.81$ & 80 \\
\hline
\end{tabular}

Table 2. Product-moment correlation coefficients (r) between dDNA concentration and basic limnological parameters of studied freshwater habitats $(\mathrm{n}=7)$. Abbreviations as in Table 1. ns: non-significant

\begin{tabular}{|lcc|}
\hline Variable & $\mathrm{r}$ & $\mathrm{p}$ \\
\hline $\log \left(\mathrm{P}_{\mathrm{T}}\right)$ & 0.742 & $\mathrm{~ns}$ \\
$\log \left(\mathrm{N}_{\mathrm{T}}\right)$ & 0.815 & $<0.05$ \\
$\log (\mathrm{BA})$ & 0.836 & $<0.05$ \\
$\log (\mathrm{VLPs})$ & 0.897 & $<0.01$ \\
$\log (\mathrm{Chl} a)$ & 0.522 & $\mathrm{~ns}$ \\
TSI $_{\mathrm{PT}}$ & 0.852 & $<0.05$ \\
\hline
\end{tabular}

rus did not. In previous studies of freshwater environments, Siuda et al. (1998) showed that when data from 14 Polish lakes and 7 German lakes were compiled, dDNA concentration correlated significantly with $\mathrm{TSI}_{\mathrm{PT}}$ and chl $a$, but not with bacterial abundance. Ishii et al. (1998) found that dDNA concentration in a hypereutrophic pond correlated significantly with rotifer and ciliate abundance, while no significant correlations were found for chl $a$ and bacterial abundance. The relationship between dDNA concentration and virus abundance has only been reported in studies of marine environments, though no significant correlations were observed (Boehme et al. 1993, Weinbauer et al. 1993). Although the data are limited, these observations may suggest that the factors involved in the dynamics of dDNA concentration vary from place to place. More data are necessary in order to discuss this in context, and the method described here would be helpful for such routine dDNA measurement. One disadvantage of this method is the expense of centrifugal filter devices. Nevertheless, using SYBR Green I dye with such a device allowed us to determine the dDNA within 3 to $4 \mathrm{~h}$ from only $10 \mathrm{ml}$ of water sample. Thus, the method shown here may be useful for monitoring the dDNA dynamics on the 'same day' in freshwater environments.

Acknowledgements. We thank the captains of the RV 'Hasu', T. Koitabashi and T. Miyano, for their cooperation in the sampling, T. Yokokawa, C. Kim, Y. Nishimura, K. Choi, M. Ueki and K. Uchii for assistance in the sampling and analysis, G. Endo for laboratory space, and Mary Morris for improving the English. This work was supported in part by a Japanese Ministry of Education, Culture, Sports, Science and Technology Grant-in-Aid for Creative Basic Research (09NP1501) and a Grant-in-Aid for Basic Research (A) (13309009). K.M. was also supported by Kurita Water and Environment Foundation and by the JSPS Fellowship for Young Scientist.

\section{LITERATURE CITED}

Boehme J, Frischer ME, Jiang SC, Kellogg CA, Pichard S, Rose JB, Steinway C, Paul JH (1993) Viruses, bacterioplankton, and phytoplankton in the southeastern Gulf of Mexico: distribution and contribution to oceanic DNA pools. Mar Ecol Prog Ser 97:1-10

Carlson RE (1977) A trophic state index for lakes. Limnol Oceanogr 22:361-369

DeFlaun MF, Paul JH, Davis D (1986) Simplified method for dissolved DNA determination in aquatic environments. Appl Environ Microbiol 52:654-659

Eaton AD, Clesceri LS, Greenberg AE (eds) (1995) Standard methods for the examination of water and wastewater. 19th edn. American Public Health Association, Washington, DC

Gurung, TB, Urabe J (1999) Temporal and vertical difference 
in factors limiting growth rate of heterotrophic bacteria in Lake Biwa. Microb Ecol 38:136-145

Ishii N, Kawabata Z, Nakano S, Min MG, Takata R (1998) Microbial interactions responsible for dissolved DNA production in a hypereutrophic pond. Hydrobiologia 380: $67-76$

Jiang SC, Paul JH (1995) Viral contribution to dissolved DNA in the marine environment as determined by differential centrifugation and kingdom probing. Appl Environ Microbiol 61:317-325

Jørgensen NOG, Jacobsen CS (1996) Bacterial uptake and utilization of dissolved DNA. Aquat Microb Ecol 11: 263-270

Karl DM, Bailiff MD (1989) The measurement and distribution of dissolved nucleic acids in aquatic environments. Limnol Oceanogr 34:543-558

Labarca C, Paigen K (1980) A simple, rapid, and sensitive DNA assay procedure. Anal Biochem 102:344-352

Lorenz MG, Wackernagel W (1994) Bacterial gene transfer by natural genetic transformation in the environment. Microbiol Rev 58:563-602

Matsui K, Honjo M, Kawabata Z (2001) Estimation of the fate of dissolved DNA in thermally stratified lake water from the stability of exogenous plasmid DNA. Aquat Microb Ecol 26:95-102

Matsui K, Ishii N, Kawabata Z (2003) Microbial interactions affecting the natural transformation of Bacillus subtilis in a model aquatic ecosystem. FEMS Microbiol Ecol 45: 211-218

Menzel DW, Corwin N (1965) The measurement of total phosphorus in seawater based on liberation of organically bound fractions by persulfate oxidation. Limnol Oceanogr 10:280-282

Minear RA (1972) Characterization naturally occurring dissolved organophosphorus compounds. Environ Sci Technol 6:431-437

Noble RT, Fuhrman JA (1998) Use of SYBR Green I for rapid epifluorescence counts of marine viruses and bacteria. Aquat Microb Ecol 14:113-118

Paul JH, Myers B (1982) Fluorometric determination of DNA in aquatic microorganisms by use of Hoechst 33258. Appl Environ Microbiol 43:1393-1399

Paul JH, Pichard SL (1995) Extraction of DNA and RNA from the aquatic environment. In: Trevors JT, van Elsas JD (eds) Nucleic acids in the environment. Methods and applica-

Editorial responsibility: Karel Šimek,

České Budějovice, Czech Republic tions. Springer-Verlag, Berlin, p153-177

Paul JH, Jeffrey WH, David AW, DeFlaun MF, Cazares LH (1989) Turnover of extracellular DNA in eutrophic and oligotrophic freshwater environments of southwest Florida. Appl Environ Microbiol 55:1823-1828

Paul JH, Cazares LH, David AW, DeFlaun MF, Jeffrey WH (1991a) The distribution of dissolved DNA in an oligotrophic and a eutrophic river of southwest Florida (USA). Hydrobiologia 218:53-63

Paul JH, Jiang SC, Rose JB (1991b) Concentration of viruses and dissolved DNA from aquatic environments by vortex flow filtration. Appl Environ Microbiol 57:2197-2204

Pillai TNV, Ganguly AK (1972) Nucleic acid in the dissolved constituents of sea water. J Mar Biol Assoc India 14: 384-390

Porter KG, Feig YS (1980) The use of DAPI for identifying and counting aquatic microflora. Limnol Oceanogr 25:943-948

Sambrook J, Russell DW (2000) Molecular cloning, a laboratory manual, 3rd edn. Cold Spring Harbor Press, Cold Spring Harbor, NY

Siuda W, Chróst RJ (2000) Concentration and susceptibility of dissolved DNA for enzyme degradation in lake watersome methodological remarks. Aquat Microb Ecol 21: 195-201

Siuda W, Güde H (1996) Determination of dissolved deoxyribonucleic acid concentration in lake water. Aquat Microb Ecol 11:193-202

Siuda W, Chróst RJ, Güde H (1998) Distribution and origin of dissolved DNA in lakes of different trophic states. Aquat Microb Ecol 15:89-96

Turk V, Rehnstam AS, Lundberg E, Hagström Å (1992) Release of bacterial DNA by marine nanoflagellates, and intermediate step in phosphorus regeneration. Appl Environ Microbiol 58:3744-3750

Vitzthum F, Geiger G, Bisswanger H, Brunner H, Bernhagen J (1999) A quantitative fluorescence-based microplate assay for the determination of double-stranded DNA using SYBR Green I and a standard ultraviolet transilluminator gel imaging system. Anal Biochem 276:59-64

Weinbauer MG, Fuks D, Peuzzi P (1993) Distribution of viruses and dissolved DNA along a coastal trophic gradient in the northern Adriatic Sea. Appl Environ Microbiol 59:4074-4082

Wetzel RG, Likens GE (2000) Limnological analysis, 3rd edn. Springer-Verlag, New York

Submitted: August 11, 2003; Accepted: February 23, 2004

Proofs received from author(s): May 24, 2004 